\title{
What Reform? Reform Stories in the Kingdom of Tonga
}

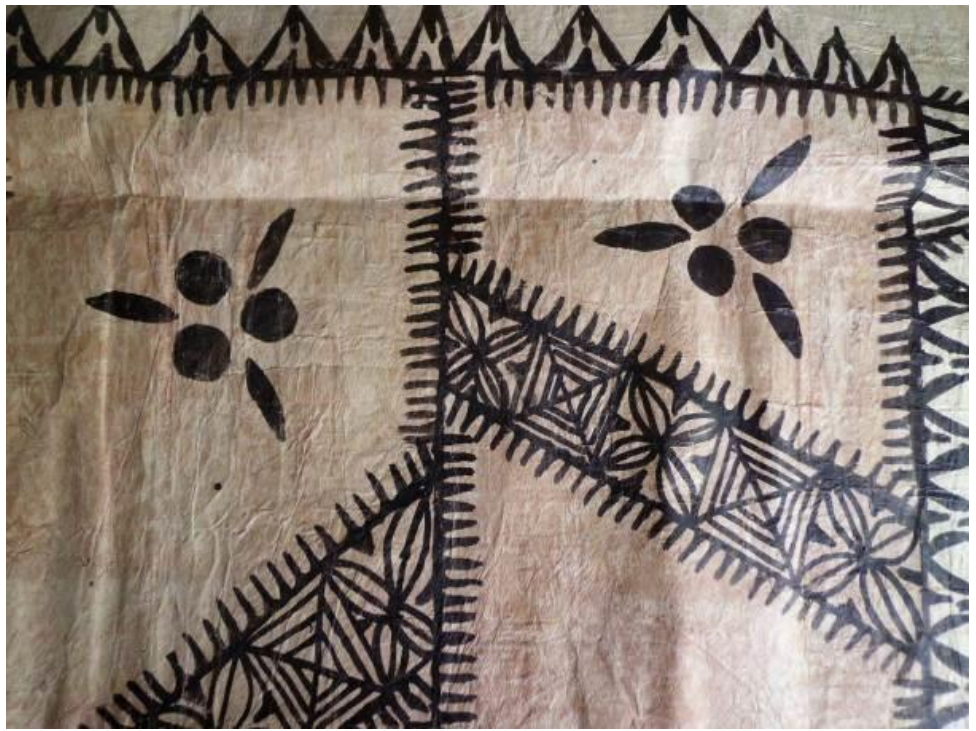

\section{Abstract}

What is the likelihood that the Kingdom of Tonga will go to a general election in 2014 and the same pool of leaders, middleaged and older men, will get voted back to parliament? For the small island developing state of Tonga that has a population of 104,509 thousand, the Legislative Assembly is elected every four years. Comprising of seventeen people's representatives voted in by constituencies of registered voters

Teena Brown Pulu has a PhD in anthropology from the University of Waikato. She is a senior lecturer in Pacific development at AUT University. Her first book was published in 2011, Shoot the Messenger: The report on the Nuku'alofa reconstruction project and why the Government of Tonga dumped it. 
on the general roll, and nine nobles' representatives voted in by the landed gentry of thirty three estate holders, historically, parliament is overpoweringly men. Tongan society's patriarchal structure and the widespread practice of Christianity as the state religion, has led to the prevalence of male political leaders being accepted as symbolic of culture.

What outside forces dismantle cultural constraints in an island Kingdom? Reform is said to be at work, stirred by Tonga's 2010 shift to a democratised state. Parliamentary representatives from the people now outnumber the nobility. So who are the reformers? Is there resistance against free market trade because farmers and fishermen have less access to business? And how do New Zealand's economic reform policies effect change for this small island nation?

\section{Reform stories}

Those who stand for nothing will fall for anything.

\section{Alexander Hamilton}

"I don't think it suits our culture," said Lord Ma'afu. Tonga's Minister for Lands and Environment was reflecting on democracy, the imported Western kind that arrives in the islands and has trouble fitting in with the Natives. Democracy thus confines itself to the bureaucracy working in high-level administration, only mixing with certain people of the social elite, the people of material means who speak English well. It mingles with Natives fluent in the language of power and foreign policy, the Natives who know the textbook frames of reference for progress, for development, for self-determination, because they were educated overseas in Western universities.

Put in this analogy, democracy could have been a white New Zealander or Australian. There were white people in Tonga that lived the description down-to-a-T, and there were brown-skinned New Zealanders and Australians of Tongan 
ethnicity who coveted the description, desiring to have it because they figured it might give them equal status with the nobility, on par with the upper class, chummy with the monarchy. Here was a human construct of power; and no matter how romantically involved with the idea that this trumped the autocratic system, and could guarantee freedom, security, equality, compared to the past method of government, it had trouble finding a fit.

By no means did democracy include, appeal to, and benefit everyone. It was a political system, a structure for governing the people. It was not the saviour, despite being talked about with human-like qualities and a personality type. Voicing that "I am disappointed with democracy" was commonplace in Tongan conversation. As if this was a person everybody knew in Tonga, and that expressing regret was going to make them buck up their ideas and demonstrate role model behaviour. In all honesty, people were dissatisfied with individuals - political leaders especially - and when they refrained from identifying folks, they named democracy as the substitute player on the national team who was not performing up to scratch and might get dropped at the next selection process. 


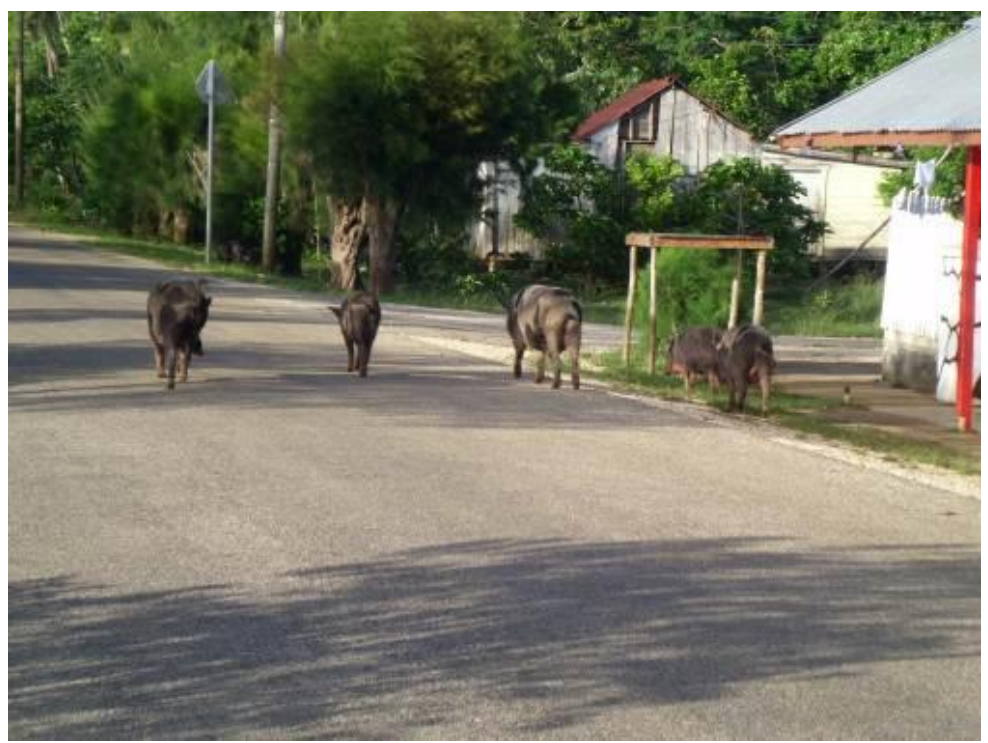

Pigs walking on the main road of a rural village in Hahake district, Kingdom of Tonga.

In May 2012, eighteen months into migrating from an autocratic to a democratic state, the deputy leader of the opposition Sitiveni Halapua had an inkling that "failed change" was in the air. Wary the "people might say that this is a failed change," Halapua knew there was disgruntlement that reform had not delivered what politicians like himself and Democratic Party leader, 'Akilisi Pohiva, had campaigned.

We have to be very careful about this. If we don't have positive, much things to show for this then it can be a disappointment. And people might say that this is a failed change, you know. (Mangnall, 2012).

Halapua defined reform in his words. To him, it meant repealing the constitutional right of the thirty three nobles to elect nine representatives to parliament from within their class group because "the people must have the right to select the 
nobles" (Magnall, 2012). One year on from Halapua's "failed change" warning to fellow politicians, both opposition and government, he was speechmaking on Radio New Zealand. His April of 2013 interview was given eighteen months out from Tonga's next general election. Switching his style up from reform knocking the nobility, he was now lobbying for political candidates in the 2014 election "to come out clearly about [their] policies" (Radio New Zealand, 2013a).

I think the people will expect candidates and particularly those who want to form the government to come out clearly about the policies they want to put in place for the country, in order to move forward. We need clear reform in that area. (Radio New Zealand International, 2013a).

Precisely, what were the Democratic Party policies? That we should reform that confusing area of reform? Kalafi Moala provided the counter to electioneering, and in the decisive moment of exposing Halapua's inept performance, highlighted that one politician armed with a $\mathrm{PhD}$ in economics was little match for Moala's home truths.

The post-democracy condition doesn't measure up to the Messianic promise proclaimed over two decades that democracy would bring solutions and help Tonga align itself with the same values driving the West - all this in the hope that the outcomes of peace, happiness, wealth, health, and social cohesion would be shared by Tongans. Never mind that none of these values are at work in the West, and worse off in the so-called third world countries that have embraced this offer of a solution by adopting democracy. (Moala, 2012). 


\section{Economic reform}

In conversation with me and another New Zealand citizen, an ex-patriate working in Tonga, we concurred with Lord Ma'afu's analysis, nodding, uttering agreement. Not because he was a high-ranking noble and a senior cabinet minister. Not because we were non-nationals in his country of birth and felt obliged to be respectful. But because he was right. In this South Seas Kingdom, democracy was a euphemism for reform. The words and meanings were interchangeable. Tongans conflated these terms in everyday speech so they came out as democratic reform or political reform, but seldom, if ever as the reference to economic reform. It was economic reform that Ma'afu pointed at and we motioned to, feeling anxious. We agreed because this was the systematic adjustment that was to displace collective ownership and the communal redistribution of wealth with private property and individual possession. We fretted because this was the kind of social change that divorced Tongan society from its origins, coercing Tongans to believe that other countries are superior and we should mimic them.

Driving the logic of capitalism in the developed world, the political ideology that private businesses own and operate a country's trade and industry, reform contained a contextspecific meaning (Schumpeter, 2008). For the Kingdom of Tonga to have democratic institutions necessitated "structural reform" by way that the state had open borders, practiced free trade, and got with the economic growth programme; the programme developed by the United States (US) in collaboration with New Zealand and Australia for the region, that is (International Monetary Fund, 2013).

If Tonga was open, it could be easily penetrated. Natural resources of the Tongan islands, in particular deep sea minerals and fisheries (Brown Pulu, 2013a, 2013b), and the small society logic that land cannot be bought by foreigners, cannot be owned by people who have no Tongan bloodline, could be reformed, modified, manipulated to fit the 
international "order of things" which was private not community ownership, and definitely not intergeneration inheritance such as the nobility's estates (Foucault, 1971). Whether the Tongan majority comprehended that democratic reform is economic integration was doubtful. No politician, not one intellectual, not even political reporters, apart from the one-off exception of Kalafi Moala, spoke and published the unthinkable realisation that democratisation had a sinister side. "Structural reform" involved getting grafted to the world's money tree as a poor country supplier of cheap raw materials and migrant labour to wealthy developed countries (International Monetary Fund, 2013). Through compliance, obedience, agreement, the supremacy of First World economies and the poverty of the Third is reinforced with them at the centre of power and us on the periphery (Wallerstein, 1979).

For the overseas settlements of Tongans in New Zealand, Australia, and the USA, public criticism of democratic reform as the preferred political arrangement did not materialise. Discontent wore blinkers. The gaze from a distance was fixed solely on political workings inside the Tongan state, paying no mind to an international economy in which Tonga was assimilated as a poor democracy that emerged from the Third World. Put under the microscope was the transfer of power from the monarch to the Prime Minister and Cabinet in that decision-making processes at the national executive level were faulted for not being accountable to the public and transparent in execution.

Exemplifying this point was Malakai Koloamatangi, a migrant Tongan to New Zealand giving his expert opinion to Radio New Zealand as a political scientist at Canterbury University. In 2010, Koloamatangi revised the Parliament of Tonga's standing orders and consulted on Tonga's democratic reform as a contributor from the pool of Tongan academics based overseas. In 2013, he was of the mind that the government needed "accountability and transparency," and 
parliament had to improve the "procedures" initiated in 2010 when he was part of the reform in-group.

A New Zealand academic says the Tonga government needs to embrace greater accountability and transparency, but is distracted by other activities, such as the infrastructure developments. Canterbury University political scientist, Malakai Koloamatangi, says once the democratic reforms were put in place 3 years ago the procedures of parliament should have been refined to ensure more democracy at higher levels. (Radio New Zealand International, 2013b).

As "a New Zealand academic," Koloamatangi was hasty to accuse Tonga's government and parliament of not achieving "more democracy at higher levels" since the 2010 "democratic reforms were put in place" (Radio New Zealand International, 2013b). But he defaulted on critiquing New Zealand's role in Tonga's democratic reform; New Zealand, the country he spoke from while pointing the finger at Tonga, and the state he paid taxes to as a New Zealand university employee. Expressly, it was the relationship tension culminating from the New Zealand Aid policy switch to economic growth, a deliberate dismantling of the former New Zealand government policy on eliminating poverty, which was unsaid and unaccounted for.

It was no foreign affairs secret that "most Pacific leaders see the change as a bad move and suggested the aid process is muddled and opaque" (Radio New Zealand International, 2013c). Likewise, it was not hush-hush that bilateral relations were strained between New Zealand and Tonga because the New Zealand Aid policy had steered clear of strengthening the community sector (Ministry of Internal Affairs, 2013; United Nations, 2011).

The sore point that flared up was that many Tongans in the homeland state felt bemused by the attitude of Tongans residing permanently in New Zealand. There was continuous 
snarling at the Kingdom of Tonga's government and parliament attempts at democratic reform from people who did not live, work, and pay taxes in Tonga. Conversely, the overseas Tongans fell silent at passing judgment on New Zealand's political takeover of Pacific Island economies.

New Zealand was instrumental in coercing Tonga into regional integration through the free trade agreements of World Trade Organisation (WTO), South Pacific Regional Trade and Economic Agreement (SPARTECA), Pacific Agreement on Closer Economic Relations (PACER), and Pacific Agreement on Closer Economic Relations Plus (PACER Plus). New Zealand as a Pacific Rim state was a member of the Trans Pacific Partnership, a US driven business arrangement granting unbridled commercial rights for multinational companies to exploit natural resources such as minerals, and monopolise local economies (Friends of the Earth US, 2013; Kelsey, 2010). For the South Pacific region, these trade arrangements intersected on one point: New Zealand and Australia maintained financial supremacy and controlled the Pacific Island states as their markets (Government of Tonga, 2013).

Why the double standard of firing reprimands one-way? How was it that Tongan critics living in New Zealand did not see the power and resourcing differentials that forced the hand of developed countries over small island developing states? And if they did catch a glimpse of the inequality, then why could they not speak back to the real power structure inside New Zealand, their country of permanent residence?

\section{Free trade}

Perplexingly, the collective of migrant Tongan academics born in Tonga, conferred with Tongan citizenship, and employed at New Zealand, Australian, and American universities, made little fuss about disproportionate regional trade, the fact that their homeland, which they took great interest in politically and culturally, was economically suffering an imbalance of 
trade with New Zealand. In 2011, Tonga exported NZD\$2 million in "root vegetables, scrap iron, fish and coconuts" to New Zealand. In return, New Zealand exported NZD\$49 million of mainly "meat, timber and petrol" to Tonga (Brown Pulu and Maka, 2011; NZ Ministry of Foreign Affairs and Trade, 2013). The math showed that aid equalled trade for developed states. Subsequent to this, fair trade for developing states was an ideal, but not common practice in dollars and good sense.

It was New Zealander Jane Kelsey, a professor of law at the University of Auckland who scolded the New Zealand and Australian governments for bullying Pacific Island states into "unconscionable demands" in free trade agreements. Tonga was the first South Pacific country in 2007 to accept a WTO raw deal resulting in tariff reductions and "foreign businesses" seizing the private sector (Cordemans, 2009). The free trade pillaging of local livelihood was rebuked by Tongan agricultural exporter Minoru Nishi who noted that "the current situation in Tonga is quite desperate in terms of the wider picture for the farmers at the grassroots level" (Pacific Network on Globalisation, 2012). The ill-fated aftermath was that "Tonga has agreed to pay that price," said Kelsey, without foreseeing that free trade undermines a nation's economic sovereignty, the foundation of a functional democracy (Cordemans, 2009).

Despicable treatment during free trade negotiations in the past have taught the Pacific Island nations to tread warily, says Professor Kelsey. Samoa, Vanuatu and Tonga have experienced "unconscionable demands" in their attempt to enter into WTO negotiations - the prospect of unfettered operations by foreign businesses, privatization and big cuts in tariffs that would reduce government revenue, she said. "To date, only Tonga has agreed to pay that price, although a statement out from Vanuatu suggests that they might 
actually be getting a bit closer to doing so." (Cordemans, 2009).

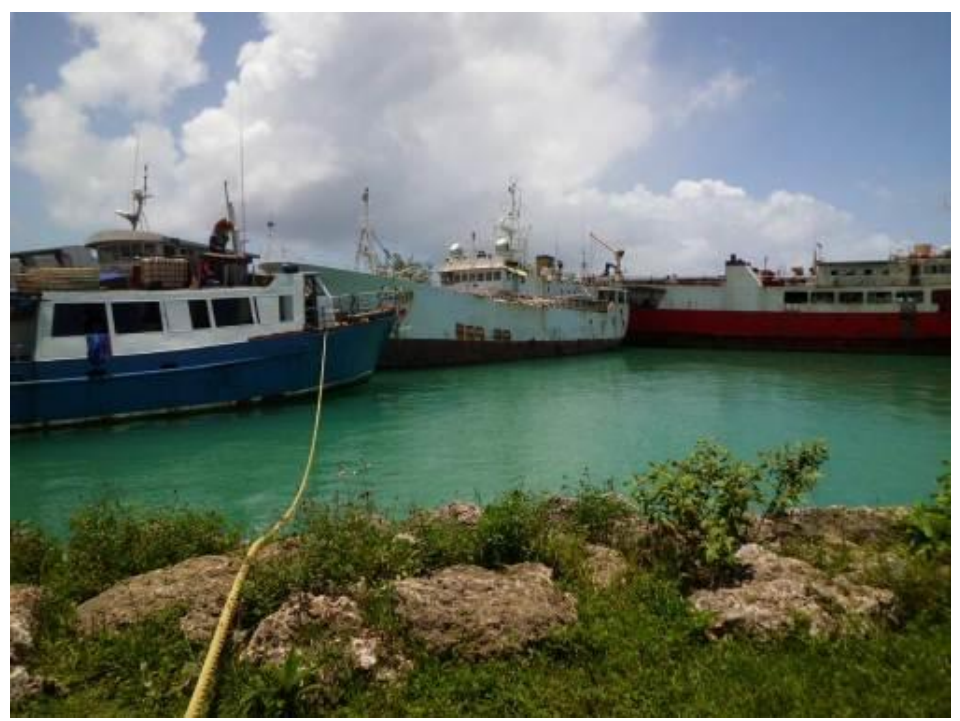

Takua (centre), the Government of Tonga's commercial fishing and research vessel which is no longer operational, anchored permanently at the Nuku'alofa waterfront, Kingdom of Tonga.

If Tonga's democratic reform resembled dysfunction as Koloamatangi suggested, then it was not by his simplistic deduction that the national system "should have been refined." Rather, Tonga's regional integration into the world hierarchy of trade agreements meant the border was open to outside business, the private sector was vulnerable to foreign occupation, and the country was susceptible to private ownership outside of Tongan hands (Moala, 2012). Parliament and government were subject to policymaking forces that were not of their country's independent sovereignty. Put bluntly, the national economy had been captured by aid donors, international banks, international money monitors, and 
foreign businesses aligned with the WTO mogul and its regional replicas of SPARTECA, PACER, and PACER Plus, which held decision-making sway over the Government of Tonga.

Disparagement of Pacific Island states uncritically taking on free trade agreements and as of consequence, decimating the local business sector, especially the primary industries of farmers and fishermen in their countries, came from nongovernment organisations in Fiji. There was a tinge of political irony: direct criticism of the New Zealand Aid policy swap to economic growth cutting out development in the Pacific Islands' community and voluntary sector was advanced from inside Fiji. This was the small island developing state tossed from the Pacific Islands Forum by New Zealand and Australia for not toeing their democracy conditions in disestablishing Bainimarama's military government by 2009 , insisting that the Fiji general election under a new constitutional arrangement would take place in 2014 (Australian Broadcasting Commission, 2009a, 2009b). And here was Fiji's nongovernment voice, checking the region's centre of power (Radio New Zealand International, 2013c; Slatter, 2006).

A spokesperson for the Pacific Islands Association for Non Government Organisations, or PIANGO, Emele Duituturaga, says her body has secured new funding after losing New Zealand backing, and is now moving on in its work. But she says many groups remain confused by New Zealand's aid approach. "It had a very strong development with integrity focus and since the change there are a lot of us who question where is New Zealand coming from and there is a perception that all this really has to be do with private sector development rather than development which is about community development. (Radio New Zealand International, 2013c). 
"There are a lot of us who question where New Zealand is coming from," said Emele Tuituturaga, but at the same time admitting that she understood the trade politics involved because "this really has to do with private sector development rather than ... community development" (Radio New Zealand International, 2013a). Tuituturaga's hunch was astute. New Zealand Aid was by no means subtle in showing its aid policy was conflated with trade. The catch was that its own economic growth was the political undercurrent. The New Zealand government engaged with South Pacific states in a double-bind, seeing these small islands under its political realm and the commercial marketplace for New Zealand businesses to tinker and trade.

\section{Energy racket}

New Zealand was expanding the business model for its aid coupled with trade operation. In Tonga, Tokelau, Cook Islands, Tuvalu, and the Bamyan Province of Afghanistan, a New Zealand brand of renewable energy had infiltrated the national energy sector of these countries (NZ Aid Programme, 2013a; Matangi Tonga, 2013b; TransNet NZ Ltd, 2013). For Tonga expressly, NZ Aid bankrolled the NZD\$7.9 million 1.32 megawatt solar plant on the main island of Tongatapu, officially opened for business on July 24th 2012 (NZ Aid Programme, 2012). Tonga Power Limited and New Zealand Aid claimed the solar plant delivered $4 \%$ of the nation's electricity, going some way to easing the rising power costs. Contrarily, Tongan households did not see the difference made to the monthly bill.

New Zealand Minister for Foreign Affairs and Trade, Murray McCully, grasped renewable energy as an opportunity for his country's expansion on the open market. First of all, 13 island states - the Marshall Islands, Federated States of Micronesia, Palau, Kiribati, Nauru, Papua New Guinea, Solomon Islands, Vanuatu, Tuvalu, Samoa, Tonga, Cook 
Islands, and Niue - who were members of the Pacific Islands Forum, had plummeted in national debt (Pacific Islands Forum Secretariat, 2013; Briguglio, 1995). Trapped twice, the second predicament was the physical deterioration of their homelands in climate change (Pelling and Uitto, 2001). They needed to step away from fossil fuel consumption to cleaner, greener, inexpensive power.

Although it was contested whether renewable energy was in fact cheaper considering that the technology was pricey and became obsolete quickly, the clean and green brand produced the magnet. Put simply, because "an overwhelming scientific consensus now supports the reduction of greenhouse gas emissions as a necessary measure to combat climate change," the islanders were captive consumers (Fischer and Preonas, 2010). New Zealand in partnership with Australia dominated regional policymaking as the developed member state couple of the Pacific Islands Forum. They held aid donor influence over small island stakeholders, holding doors open or shut to labour migration flows of workers from Kiribati, Samoa, Tuvalu, Tonga, Solomon Islands, and Vanuatu, requiring temporary visas for Recognised Seasonal Employer (RSE) schemes run on New Zealand and Australian orchards (Hughes, 2003).

To the New Zealand press, McCully announced that "the new power plant [in Tonga] showed other Pacific governments that a switch to renewable energy could be done. New Zealand has already started talks with potential investors in the European Union and Asian Development Bank" to expand business and sell more (Migone, 2012). The logic was, if McCully could get these "other Pacific governments" hooked, his country had an advantage over the market monopoly.

A reliable, affordable energy supply is fundamental to economic development. It is essential for productivity across sectors, and increases efficiency of everyday household tasks. Many of New Zealand's developing 
country partners have energy sectors that are inadequate to support sustainable economic growth. New Zealand is investing \$6 million over the next three years to upgrade the village and peri-urban power distribution network on Tongatapu. It is also creating jobs and industry training for 10 Tongan linesmen. At the conclusion of the project, the 10 trainees will have fully certified qualifications with New Zealand standards. (NZ Aid Programme, 2013a, p. 34).

There were entangled factors that the New Zealand aid programme did not advertise in their "affordable energy supply is fundamental to economic development" marketing drive (NZ Aid Programme, 2013a, p. 34). Notably, Meridian Energy, the New Zealand government's state-owned electricity and renewable energy company, was contracted under the New Zealand aid programme to build Tonga's solar farm "made up of 5,760 photovoltaic solar panels" with the capability to produce "1.32 megawatts of electricity" (Meridian Maama Mai, 2013). Meridian announced that "this is the first solar farm we've built in the Pacific, and the first renewable energy generation facility connected to Tonga's electricity grid" (Meridian Maama Mai, 2013). 


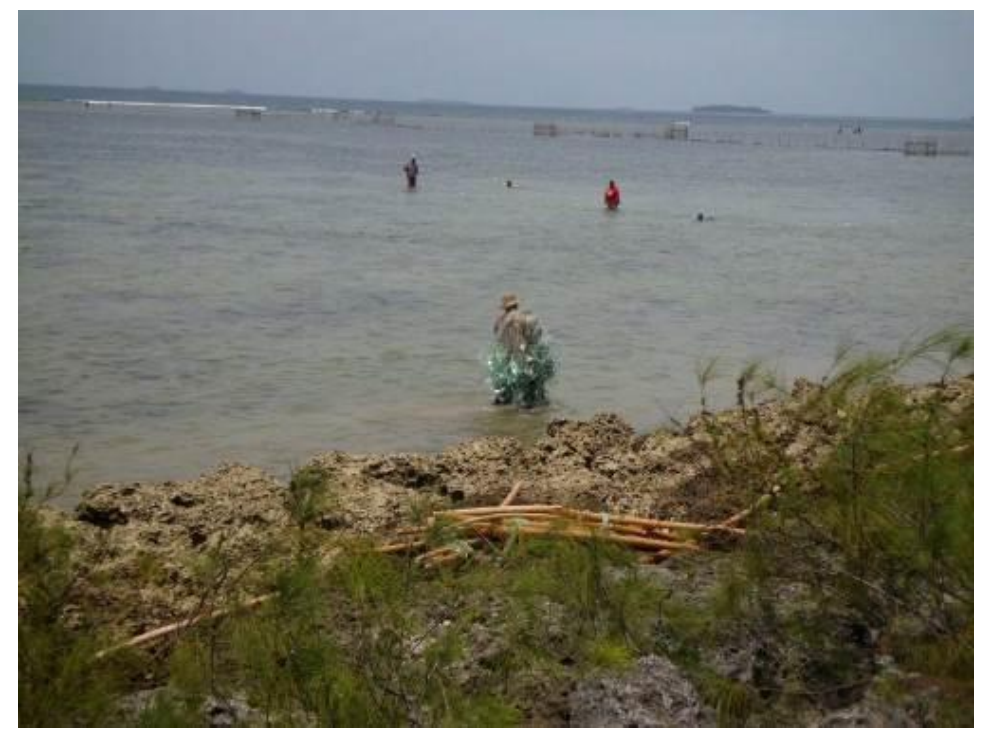

Tongan families gathering seafood and checking fish traps in the coral reef at Sopu, Kingdom of Tonga.

What McCully's press statement publicised is that the New Zealand government planned to reproduce the Meridian model for "other Pacific governments" (NZ Aid Programme, 2013a, p. 34). In practice, funds invested in the New Zealand aid programme to subsidise renewable energy would be paid out to Meridian Energy as the contractor, "the lead developer on the project" that traded New Zealand's brand regionally (Meridian Maama Mai, 2013). Criticism from inside the Tongan state wielded a sharpened double-edge. How was it that the New Zealand government was in favour of Pacific Island states freeing up state-owned enterprises to private sector control, when it promoted and paid for the business of its state-owned power company with aid money?

Subsequent to this, when the New Zealand government bankrolls its aid programme to contract its power company to replicate its own brand of renewable energy across the region, what financial assistance is prioritised for the economic 
growth of local industry development in the Pacific Island states? Was McCully's "industry training for 10 Tongan linesmen" the aid package for "private sector development?" (NZ Aid Programme, 2013a, p. 34; Radio New Zealand International, 2013c).

\section{Forget carbon emissions}

Resultant of the green energy industry creating customer demand in the Pacific Islands, a development discrepancy unfolded. It was apparent that the New Zealand Aid angle was propelled by exporting renewable energy merchandise regionally. But peddling renewables did not mean that this aid donor was unequivocally dedicated to climate change in the Pacific. New Zealand, a developed country located in the Southern Hemisphere, flatly refused to accept the United Nations (UN) legally binding carbon emission cuts from 2012 to 2020 .

It was a judgement that positioned "it at odds with Australia and 36 other industrialised nations" (Stuff NZ, 2012). Strategically, New Zealand separated itself from the policy stand of member states to the Pacific Islands Forum. What were the political manoeuvrings about in playing the donor and trader roles at the same time? Would New Zealand's relationships dampen for not toeing the official line that climate change threatened the continued existence of the Pacific Islands?

A curly story uncoiled. From the outset, New Zealand nose-dived at ratifying the Kyoto Protocol amended during the UN Climate Change Conference in Doha from November 26th to December 8th 2012. Unwilling to do its part to reduce the world's carbon emissions of greenhouse gases by 2020 according to UN specifications, it was state liability for failing to curtail the developed country discharge polluting the Third World, particularly vulnerable regions such as the Pacific Island states, that New Zealand would not assent to (The 
Economist, 2012; Asia-Pacific Network for Global Change Research, 2012). On closer inspection, there were country-tocountry disparities. New Zealand and Tonga highlighted the fact that trade exploited aid. In 2011, the New Zealand aid programme invested NZD $\$ 18$ million in Tonga, while its exporters went about "providing 40\% of Tonga's imports ahead of Fiji, Australia, the United States and China" (NZ Ministry of Foreign Affairs and Trade).

Through bilateral collaborations New Zealand had crafted a self-styled approach to doing development. The bureaucracy prudently aligned Pacific Island states under the policy regime of the Ministry of Foreign Affairs and Trade, allowing the machinery of government to perform a curious function. It distributed aid, regulated by the trade ministry. An unswerving motive was the political driver: Increasing New Zealand's commerce and trade was the purpose of transacting aid (NZ Aid Programme, 2013b).

On July 13th of 2011, a "Joint Commitment for Development" signed between the New Zealand Minister for Foreign Affairs and Trade and Tonga's Prime Minister ranked bilateral dealings under " 6 priority sectors [of] energy, small to medium enterprise development, tourism, education and training, police, budget support" (Tonga - New Zealand Joint Commitment for Development, 2011; NZ Aid Programme, 2013b). Despite the aid donor testimony of "increased support for sustainable economic development activities, while focussing on the specific development challenges in Tonga," the truth emerged. Renewable energy was expedient. It suited the trade-driven model stipulating how New Zealand Aid operated in the Pacific (NZ Aid Programme, 2013b).

Steered by politicking not research-driven policy, the Government of Tonga had put all of its development eggs into one renewable energy basket. Staring climate change in the face, this small island developing state did not take in the full view. In practice, the size and scale of climate adaptation projects and policies were not confined to, or anchored on, 
renewable energy (Council of the European Union, 2009; European Commission, 2012; European Union, 2012). Greenhouse gases produced by industrialised countries were the fundamental cause of the planet's poor health, requiring legal restraint and penalties for breaches.

\section{Climate trade-off}

A climate trade-off transpired. Tonga got one solar farm and applied no political pressure on New Zealand to adopt the UN terms for reducing carbon emissions. At the international table, there was the Alliance of Small Island States (ASOS) of which Tonga was an affiliate. Chaired by the Republic of Nauru, this inter-government organisation of 39 member states predominantly from the Pacific and the Caribbean petitioned for climate justice under the United Nations Framework Convention on Climate Change (United Nations, 1998; Crocker, 2012; Talakai, 2012; Australian National University, 2013). ASOS had little, if any effect, on modifying New Zealand's stance. How was it, that New Zealand had the authority to remove Fiji from the Pacific Islands Forum for non-compliance with its rules of democracy, but when it came to breaking the other members' rules on reducing carbon emissions, it got its own way?

The Tongan strategy of waving a climate change signboard at regional and international forums, but limiting the national demonstration to renewable energy, meant the bilateral affair with New Zealand was done on the sly down in the bargainbasement. To explain, the aid that might have been allocated to small and medium businesses, used for farmers and fishermen needing stimulus packages to get markets and trade for their livelihood, was consumed by renewable energy. The Tonga Energy Road Map (TERM), the national strategy aimed at implementing $50 \%$ renewable sources by 2020 , had eaten into the New Zealand Aid allowance relinquishing other sectors' access to development assistance. 
Lord Tu'ivakano was the key figure demonstrating partiality to the Tonga Energy Road Map (TERM), making it the centre point of his four-year office as prime minister from 2010 to 2014. Aggressively, he pursued aid over trade; aid to bankroll TERM, aid for state budget support, aid as an addictive dependency (Hughes, 2003; King, 1967). Whether his cabinet ministers supported their head of government's fixation on TERM above all development sectors in this South Pacific Kingdom, including export trade for farmers and fishermen, was debatable. What was certain is that the premier's wilful exercise of power in heading the energy quest for renewables gave his pet project the top spot.

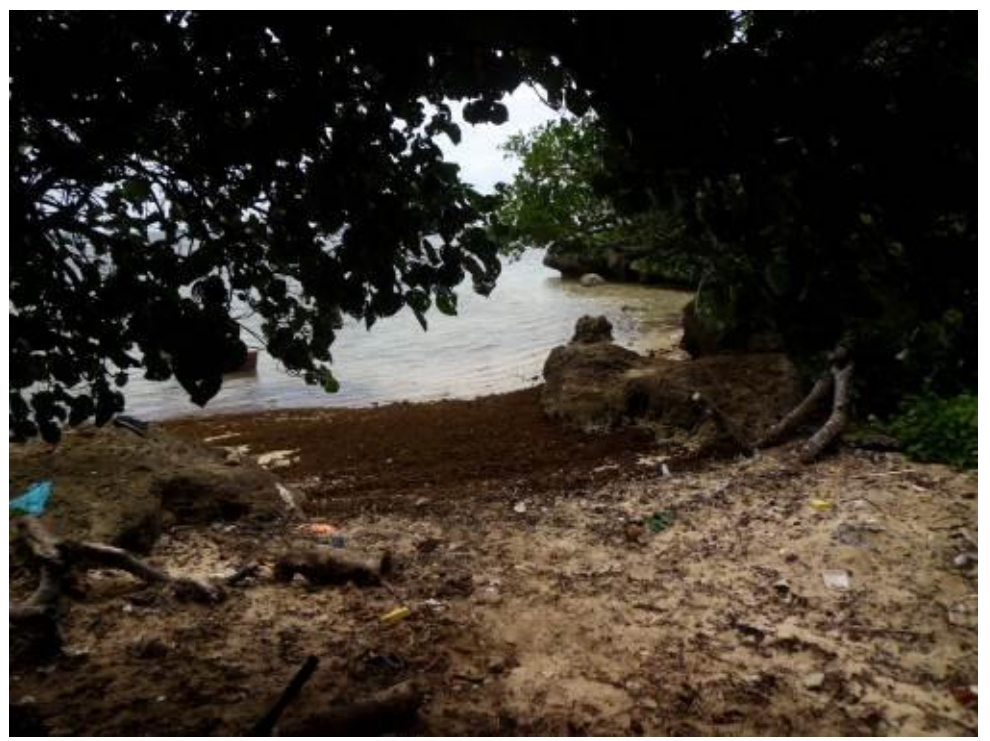

A littered beach cove which has had its coral sand removed and used by locals for property development and road construction in Kolonga, Hahake district of the Kingdom of Tonga.

The prime minister's preoccupation with TERM went unquestioned by the government, the parliament, the media, 
and the public. Private conversations uttered widespread speculation about the director of the TERM implementation unit. He was said to have been remunerated USD $\$ 180$ thousand per annum, and the TERM consultant paid USD\$360 thousand per annum; higher salaries than what the prime minister and cabinet ministers got paid. Contrary to the state freedom of information policy, the government provided no public detail of how the European Union's (EU) 2008 donation of 6.8 million Euros, and 2013 gift of 6.5 million Euros, was spent on the actual implementation of renewable energy projects for the public good (Matangi Tonga, 2008, 2013a).

Was this democratic reform? In a nutshell, no, it did not match up with procedures of consensus driven decisionmaking at the national executive and fiscal accountability to the public. By comparison, in a coconut shell, it was a course of action indicative of high-level Tongan state politics and not out-of-sorts with how arbitrary judgements were made short of sounding out fellow decision-makers, getting their say-so, and sticking to the bureaucracy's administrative system.

Peer recognition that TERM was the Tu'ivakano government trademark, Tonga's national development project being pushed as the role-model to duplicate throughout the region came from Neroni Slade, the Secretary General of the Pacific Islands Forum Secretariat. Slade commented that "a Secretariat peer review team will start work on the TERM case study" to "produce valuable information" (Pacific Islands Forum Secretariat, 2013a, 2013b). Research into what exactly, considering that Tonga desired $50 \%$ renewables by 2020 and had 4\% in hand, was not clear; not that clarity was the Secretary General's point (Firth, 2006). He was making a political speech, patting TERM on the back.

"I am pleased to note that a Secretariat peer review follow up team will start work on the TERM case study this month and will liaise with the World Bank and 
other relevant stakeholders on the details of the requisite work," said the Secretary General. "I am certain that the case study will produce valuable information to provide further guidance to the Government of Tonga, and I'm sure to the region, in the implementation of the TERM." (Pacific Islands Forum Secretariat, 2013a).

\section{The south exists}

"The south exists" said former Venezuelan president Hugo Chavez, rightly commenting that "the future of the north depends on the south" (Sojo, 2005). The political irony was that the apparatus of economic reform - the privatisation of state assets and free market trade - had done more to worsen the unequal distribution of wealth between north and south, than put an end to it (Kelsey, 1993; Schumpeter, 2008).

The south also exists. The future of the north depends on the south. If we don't make that better world possible, if we fail, ...the world will be destroyed. ...Privatization is a neoliberal and imperialist plan. Health can't be privatized because it is a fundamental human right, nor can education, water, electricity and other public services. They can't be surrendered to private capital that denies the people from their rights. (Sojo, 2005).

The unique situation in the South Pacific is that New Zealand and Australia, developed countries that are Western in democracy and national gross domestic product (GDP), meaning the market value of their economies, symbolise the north. They represent the northern hemisphere's power, wealth, and European imperialism in the south, giving the impression of close proximity to the small island developing states, but always one over them, one up on them, one better 
than them. This relationship has endured into the $21 \mathrm{st}$ century as the interface between us, the superior West, and them, the lesser others. Tracing its relationship roots to 19th century colonial administrations and church missions in the South Pacific, New Zealand in particular, is deeply ambivalent about engineering the kind of social change where the others, the Natives of Pacific Island states, could possibly transcend Western inscriptions of smallness, isolation, poverty, backwardness, dependency, and inferiority.

What I am saying is that successive colonial and 20th century New Zealand governments created an identity connection to the South Pacific oriented in being its minder and keeper. As paternalistic and patronising as this might seem, it is what Edward Said described as "the result of cultural hegemony at work which gives [this identity connection] its durability and strength" to have power and exert influence in the present day (Said, 1978, p. 7). Said explained "cultural hegemony" in this way.

It is never far from what Denys Hay has called the idea of Europe, a collective notion of identifying "us" Europeans as against all "those" non-Europeans, and indeed it can be argued that the major component in European culture is precisely what made that culture hegemonic both in and outside Europe: the idea of European identity as a superior one in comparison with all the non-European peoples and cultures. (Said, 1978, p. 7).

"The idea of Europe" as the modern icon of cultural hegemony was prevalent in the political ethos of Tonga's 2010 democratic reform. The twist was, however, that in terms of Europe being attributed as democracy's origin moment, this was not an ideology which had gathered traction with prodemocracy activists, community lobbyists, and church leaders. For ordinary Tongans, there was little, if any connection 
between "the idea of Europe" representing the people's democracy, the real "history from below" (Bhattacharya, 1983). Instead, it resonated in history from above as recalled in the views of the late monarch and reformer, King George Tupou V (Hill, 2010).

Like others of my generation, my education has generally been a liberal European and I feel sure that without a European education, with a solely Tongan education, I don't believe that I would have been able to make these changes. (Hill, 2010).

This was the discrete cultural and historical context, setting Tonga's reform apart from Western developed countries, as well as other Pacific Island states that had adopted a Western modular form of democratic government. Tonga's brand of democracy would never be solely a people's movement from below, socially detached from the monarchy and the nobility. Reform in the Kingdom of Tonga was dependent on assent from the throne, which in turn required the cooperation and consent of the nobility.

As Edward Said remarked, "there is nothing mysterious or natural about authority" because power is founded in social and political institutions, and it is institutional power which characterises how knowledge is constructed, and controls what gets circulated to whom (Said, 1978, p. 19).

There is nothing mysterious or natural about authority. It is formed, irradiated, disseminated; it is instrumental, it is persuasive; it has status, it establishes canons of taste and value; it is virtually indistinguishable from certain ideas it dignifies as true, and from traditions, perceptions, and judgements it forms, transmits, reproduces. Above all, authority can, indeed must, be analysed. (Said, 1978, pp. 19-20). 
If there was a puzzling aspect to reforming the Tongan state, then it was not the method in which economic reform overtook and displaced political and social transformation. That was to be expected in the midst of a global downturn where the force of the free market and multinational corporations had sunk the world economy. What was surprising is that Tonga had arrived at a transition point in its 21 st century history, a time when "authority indeed must be analysed" to make collective sense of changes the country was experiencing (Said, 1978, p. 20). But the intellectuals, the writers, the social critics, the activists, whose role was to provide an informed critical commentary, had gone quiet. What did the cautious restraint suggest about the status and productivity of democracy's fifth estate, that is, the media, the researchers, the information networks, the communications industry? (Strelitz and Steenveld, 1998).

\section{My generation}

A colleague from Eastern Europe asked me, "am I right to say that you were reluctant to criticise the prime minister in your book?" She was talking about Shoot the Messenger, a book I authored (Brown Pulu, 2011). To cut a long story short, in 2011 I got fired by the Prime Minister's Office at the Government of Tonga for writing a report about the Nuku'alofa reconstruction project, slamming the prime minister's advisors for ill-advising the boss. I wrote a book about the ordeal publishing the bothersome report that gave me trouble. The prime minister is my matrilineal uncle. In a small island society, the fact he was my blood relative, a noble, and the prime minister, overshadowed any interest in the report I wrote with overwhelming curiosity as to how on earth I could have contemplated such an act; upsetting my very important uncle so bad he terminated me from his office. Who does that in Tonga? I did, quite frankly.

In the Kingdom of Tonga, it was perceived that I had crossed a boundary; not singly by speaking up to the 
government but rather, because my uncle was the head of government there was an expectation I comprehended a different social protocol applied to me. Understandably he could, indicating there was likelihood he would, take criticism from me directed at him personally; which he did by executing my sacking order.

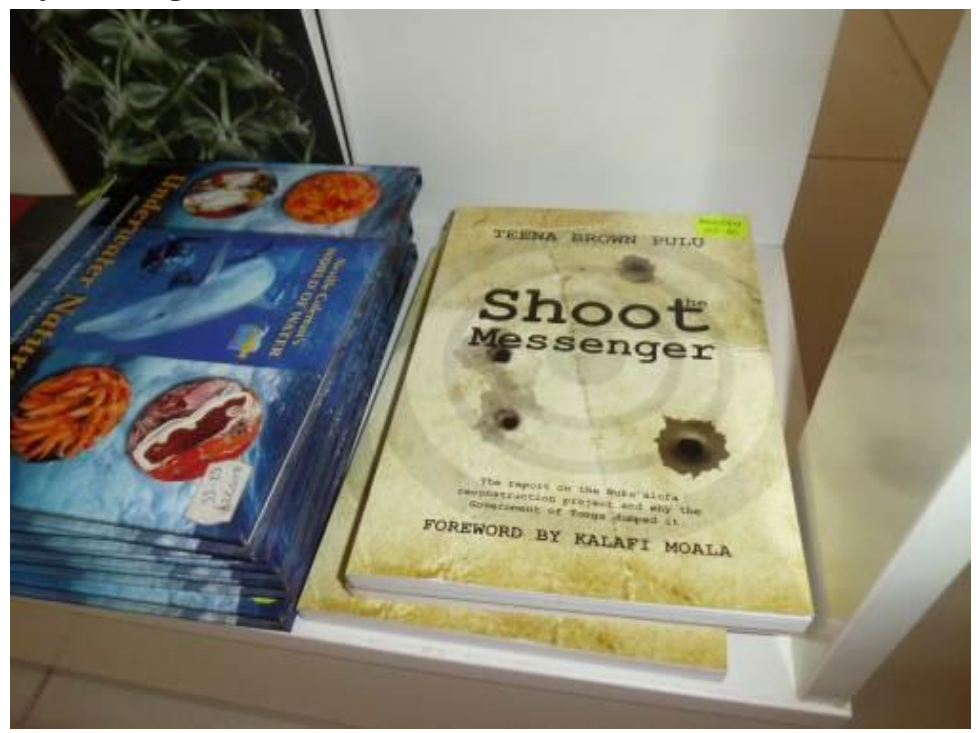

"Shoot the Messenger" on sale for TOP\$35 at the Friendly Islands Bookshop in Nuku'alofa, Kingdom of Tonga.

We were family and I was a niece, a younger female, a halfcaste; and one that was born in New Zealand not Tonga; one that spoke English as my first language not Tongan; one that was not socialised by Tongan culture; one that did not wear a Tongan ta'ovala nor dress modestly in a vala tupenu down to my ankles. I did, however, wear jandals. These cultural defects piled on the weight to my overburdened list of drawbacks. I felt obese wearing all of my shortcomings, despite weighing 63 kilograms and being told by Tongans I was too skinny and too pretty, which possibly was a cultural 
climate warning that I appeared to be foot loose and fancy free, a wild woman, by conservative Tongan estimations.

A fellow academic from AUT University put to me, "am I right to say that you were reluctant to criticise the prime minister in your book?" Immediately I gazed at the European, one with an Eastern European accent in spoken English that was hard for me to understand. For that is what I saw: A white-skinned European historically framed by Denys Hay's "idea of Europe, a collective notion of identifying "us" Europeans as against all "those" non-Europeans" (Said, 1978, p. 7; Hay, 1968). This European from the north, out-of-place in the south, made an ignorant and clumsily articulated inquiry. Even after reading my book where I narrated my familial relationship to Tonga's prime minister, showing that I had affection for this man despite our differences, she contravened the southern etiquette.

The European did not comprehend that almost two hundred years of colonialism through to political independence in the South Pacific had developed a system of cultural proscriptions and prescriptions between different peoples of colour, culture, and class. Contextually, it shaped how white people and Natives navigated their way through conversations without haphazardly treading on each other's colour coded and deeply loaded sensitivities. It constructed the testing ground for knowing when borders had been infiltrated by a transgressor who was treacherously trampling on territory, on people, they did not belong to and had no right to walk into.

The European was not attuned to the difference between north and south, figuring that because we were located in the university, freedom of intellectual thought happened without heightened awareness of who one is speaking to, and how the speaker will be judged by their insider or outsider relationship to the subject being discussed. Initiating dialogue by the selfimportance of her own opinion she exclaimed, "am I right to say?" No, you are wrong to assume that your voice is 
significant to this subject, to this story. I am the subject. It is my story. I will tell it.

Kai Davis stressed the cultural politics stirred in conversations where a white person poses a query that really, seeks affirmation from the other, who happens to be a person of colour, that their opinion about the other's culture is correct. As Davis observed, the instigator of the dialogue is oblivious to any wrongdoing embedded in their comments, surfacing in their desire to forge closeness with the other's lived experience. Applying this to my predicament, the European was unknowing of my Tongan reality in that I was incensed because "your privilege is still the most prominent thing about you," and "we don't need to hear your feelings about our issues" (Davis, 2012).

What occurred in the moment of the probe, "am I right to say?" is that she became positioned in, and advantaged by, her own history. "The idea of Europe" confronted me; an interrogation aimed straight at my culture from the dominant power over the world's peripheral states, "the people without history" on their side, the most vulnerable and marginalised, which in the south was the Pacific Island countries (Wolf, 1982; Wallerstein, 1979).

I don't see colour. What you meant to say was, oh, I'm truly going to deny your personal identity inherited in order to make me feel more comfortable. Is that racist? Yes, it is. And we don't mean to offend you by calling you racist. We know that according to you we're all part of the human race. When your privilege is still the most prominent thing about you: We don't need to hear your feelings about our issues. (Davis, 2012).

In 2003 when I entered the University of Waikato PhD programme in anthropology, I had a naïve agenda to modify Tongan scholarship. I wanted the intellectual favouring of conservative culture, church conformity, and traditions of 
hierarchy and patriarchy to be faced up to, argued with, unpicked, and open to people like me (Foucault, 1971). People of difference, people of mixed-ethnicity and cross-pollination, people born and raised outside of the ancestral homeland who were no less Tongan in allegiance, sensitivity, sensibility, were the people I spoke up for (Brown Pulu, 2007).

Ten years on in 2013 as a mid-career academic, I am still dedicated to intellectual reform with a will to write back to the powerful manufacturers of knowledge about us, the South Pacific's small island developing states. It is them, "the idea of Europe" and its colonies, New Zealand and Australia, that govern over knowledge production and guard the authority to define and confine what is considered factual and true (Said, 1978, p. 7). Through acts of writing, critiquing, and speaking back to the power structure, the internal politics ranking how Tongan or un-Tongan I am inside the cultural hierarchy become inconsequential to the actuality that I am the voice of an insider inside academia. My point is there would be little self-representation, little insight outside "the idea of Europe" as the omnipotent source of knowledge, if I and others of my generation were not inside academia writing back to the centre (Spivak, 1990; Hooks, 1989).

This is what my generation brings to the reform table, the first generation of Tongans born overseas. The will to tell our stories without outsiders interpreting, interfering, intervening, interacting as ventriloquists that speak about us, talk for us, mediate to the world on our behalf, when we can accomplish these roles with specialised knowledge that only we have lived experience of. In closing, the sentiments of Vaimoana Niumeitolu accentuate the reform stories of my generation. The words of a young Tongan American woman, intellectual, activist, and performing artist, her message evokes and echoes that change can, if carried out, give voice to "silent storytellers" from small islands of Oceania (Niumeitolu, 2010). 
We go about our lives passing, never telling our stories, leave it for someone else to do and tell, Silent Storytellers. ...Let us break the myths that hold us down, call us ugly, betray each other and ourselves. Let us be our own Creators of our own Lives. (Niumeitolu, 2010). 


\section{References}

Asia-Pacific Climate Change Adaptation Forum. (2013). 3rd AsiaPacific Climate Change Adaptation Forum: Mainstreaming Adaptation in Development: Strategies and Actions in a Changing Climate. Incheon, Korea, March 18-20. Retrieved from

http://www.asiapacificadapt.net/adaptationforum2013/

Asia-Pacific Network for Global Change Research. (2013). Formation of an Asia-Pacific Forum on Loss and Damage Announced in Incheon, Korea. Asia-Pacific Network for Global Change Research, Kobe, Japan, March 20. Retrieved from

http://www.apn-gcr.org/2013/03/20/formation-of-an-asia-pacificforum-on-loss-and-damage-announced-in-incheon-korea/

Australian Broadcasting Commission. (2009a). 'No Place' for Fiji in Pacific Forum. Australian Broadcasting Commission News, Melbourne, Australia, May 2. Retrieved from

http://www.abc.net.au/news/2009-05-02/no-place-for-fiji-in-pacificforum/1670376

Australian Broadcasting Commission. (2009b). Fiji Suspended from Pacific Islands Forum. Australian Broadcasting Commission News, Melbourne, Australia, May 2. Retrieved from

http:/ / www.abc.net.au/news/2009-05-02/fiji-suspended-frompacific-islands-forum/1669788

Australian National University. (2013). UN Climate Change Negotiations: The Role and Influence of the Alliance of Small Island States. Outrigger: Blog of the Pacific Institute, Australian National University, Canberra, Australia, February 26.

http://asiapacific.anu.edu.au/blogs/pacificinstitute/2013/02/26/un -climate-change-negotiations-the-role-and-influence-of-thealliance-of-small-island-states/

Bhattacharya, S. (1983). History from Below. Social Scientist, 11 (4): 320.

Briguglio, L. (1995). Small island developing states and their economic vulnerabilities. World Development, 23 (9): 1615-1632.

Brown Pulu, T. (2007). Kakai Tonga 'i 'Okalani Nu'u Sila: Tongan Generations in Auckland New Zealand. Unpublished PhD Thesis in Anthropology, University of Waikato, Hamilton, New Zealand.

Brown Pulu, T. (2011). Shoot the Messenger: The Report on the Nuku'alofa Reconstruction Project and Why the Government of Tonga Dumped It. Kingdom of Tonga: Taimi Publishers.

Brown Pulu, T. (2013a). Deep Sea Tension: The Kingdom of Tonga and Deep Sea Minerals. Te Kaharoa: The e-Journal on Indigenous Pacific Issues, 6 (1): 50-76. Retrieved from

http://www.tekaharoa.com/index.php/tekaharoa/article/view/145/1 $\underline{03}$

Brown Pulu, T. (2013b). Fish Tales: Local Fishing in the Kingdom of Tonga. Te Kaharoa: The e-journal on Indigenous Pacific Issues, 6 (1): 77-109. Retrieved from

http://www.tekaharoa.com/index.php/tekaharoa/article/view/146/1 $\underline{04}$ 
Brown Pulu, T. and Maka, M. (2011). Tonga Agro-Exports: Action Plan. Government of Tonga, Prime Minister's Office, Nuku'alofa, Kingdom of Tonga, March 28.

Cordemans, D. (2009). Pacific Islands Bullied by Australian, NZ Trade Officials, Says Experts. The Epoch Times, New York, USA, May 30. Retrieved from

http://www.theepochtimes.com/n2/new-zealand/kelsey-pacificislands-forum-17534.html

Council of the European Union. (2007). EU Strategy on Aid for Trade: Enhancing EU Support for Trade-Related Needs in Developing Countries. Brussels, Belgium, October 29. Retrieved from

http://trade.ec.europa.eu/doclib/docs/2008/november/tradoc_1414 70.pdf

Crocker, M. (2012). Press Release: 100 Countries Stand United on Kyoto Protocol in Doha. Alliance of Small Island States, Washington DC, USA, November 2012. Retrieved from

http://aosis.org/press-release-100-countries-stand-united-on-kyotoprotocol-in-doha/

Davis, K. (2012). Brave New Voices 2012 Finals: Philadelphia Round II. Brave New Voices 2012, Oakland, USA, July 22. Retrieved from http:/ / www.youtube.com/watch?v=19Avq8QPUO8

European Commission. (2012). New EU-Pacific partnership to tackle climate change and fight poverty: Press Release. European Commission, Brussels, Belgium, April 4. Retrieved from

http://europa.eu/rapid/press-release_IP-12-364_en.htm

European Union. (2012). Paving the Way for Climate Compatible Development: Experiences from the Global Climate Change Alliance. London, United Kingdom: European Commission, Pp. 160.

Firth, S. (Ed). (2006). Globalisation and Governance in the Pacific Islands. Canberra, Australia: ANU E Press.

Fischer, C. and Preonas, L. (2010). Combining Policies for Renewable Energy: Is the Whole Less than the Sum of Its Parts? Discussion Paper, Resources for the Future, Washington DC, USA, March, Pp. $1-41$.

Foucault, M. (1971). The Order of Things: An Archaeology of the Human Sciences. New York, USA: Random House Incorporated.

Friends of the Earth US. (2013). Peril in the Pacific: No to the Trans Pacific Partnership. Friends of the Earth US, Washington DC, USA, May 7. Retrieved from

http:// www.youtube.com/watch?v=LW-TEHIScvw

Government of Tonga. (2013). Expression of Interest: Tonga Trade Representative, Auckland, New Zealand. Ministry of Commerce, Tourism and Labour, Nuku'alofa, Kingdom of Tonga, March 18. Retrieved from

http://matangitonga.to/ad/2602-mctl-eoi-tonga-trade-rep-18-march8-april-2013

Hay, D. (1968). Europe: The Emergence of an Idea. Scotland, United Kingdom: University of Edinburgh Press. 
Hill, B. (2010). King Tupou V Speaks to Radio Australia. Australian Broadcasting Corporation News, Melbourne, Australia, November 22. Retrieved from

http://www.abc.net.au/news/2010-11-22/king-tupou-v-speaks-toradio-australia/2346566

Hooks, B. (1989). Talking Back: Thinking Feminist, Thinking Black. Cambridge, Massachusetts, USA: South End Press.

Hughes, H. (2003). Aid Has Failed the Pacific. Issue Analysis, 33 (May): 1-32.

International Monetary Fund. (2013). International Monetary Fund: Press Release No 13/92: IMF Concludes the 2013 Article IV Consultation Mission to the Kingdom of Tonga. International Monetary Fund, Washington DC, USA, March 26.

http://www.4-traders.com/news/IMF-International-Monetary-FundPress-Release-IMF-Concludes-the-2013-Article-IV-ConsultationMi--16582435/

Kelsey, J. (1993). Rolling Back the State: Privatisation of Power in Aotearoa / New Zealand. Wellington, New Zealand: Bridget Williams Books.

Kelsey, J. (2010). Professor Jane Kelsey on the Trans Pacific Partnership. The Green Planet FM Podcast with Tim Lynch, Auckland, New Zealand, December 23. Retrieved from

http://www.greenplanetfm.com/members/greenradio/blog/VIEW/00 $000001 / 00000128 /$ Professor-Jane-Kelsey-on-the-Trans-PacificPartnership-Agreement.html\#00000128

King, M. L. (1967). The World House. Where Do We Go From Here: Chaos or Community? New York, USA: Harper and Row Publishers.

Magnall, K. (2012). Tonga - The Future: Insight. Radio New Zealand National, Nuku'alofa, Kingdom of Tonga, May 6. Retrieved from

http://www.radionz.co.nz/national/programmes/sunday/audio/2517 750/insight-for-6-may-2012-tonga-the-future

Matangi Tonga. (2008). EU to Provide $\$ 10$ Million for Tonga Renewable Energy. Matangi Tonga Online, Nuku'alofa, Kingdom of Tonga. Posted by Pacific Islands Report, East-West Center, Honolulu, Hawai'i, USA. Retrieved from

http://pidp.org/archive/2008/May/05-16-14.htm

Matangi Tonga. (2013a). EU bolsters Tonga's National 'Energy Road Map'Plan. Matangi Tonga Online, Nuku'alofa, Kingdom of Tonga, March 27. Posted by Pacific Islands Report, East-West Center, Honolulu, Hawai'i, USA. Retrieved from

http://pidp.eastwestcenter.org/pireport/2013/March/03-28-13.htm

Matangi Tonga. (2013b). Pacific Leaders Energy Summit Opens in Tonga. Matangi Tonga Online, Nuku'alofa, Tonga, March 21. Posted by Pacific Islands Report, East-West Center, Honolulu, Hawai'i, USA. Retrieved from

http://pidp.eastwestcenter.org/pireport/2013/March/03-22-11.htm

Matangi Tonga. (2013c). Tonga Trials Solar-Powered Street Lights in Capital. Matangi Tonga Online, Nuku'alofa, Tonga, January 29. 
Posted by Pacific Islands Report, East- West Center, Honolulu, Hawai'i, USA. Retrieved from

http://pidp.eastwestcenter.org/pireport/2013/January/01-3006.htm

Meridian Maama Mai. (2013). Maama Mai. Meridian Energy, Christchurch, New Zealand, April 9. Retrieved from

http://www.meridianenergy.co.nz/what-we-do/our-powerstations/solar/maama-mai/

Migone, P. (2012). NZ-funded solar facility opens in Tonga. Stuff NZ, Auckland, New Zealand, July 24. Retrieved from

http://www.stuff.co.nz/world/south-pacific/7339528/NZ-fundedsolar-facility-opens-in-Tonga

Ministry of Internal Affairs. (2013). Statement by Lord Vaea: 57th Session Commission on Status of Women. Tonga Government Portal, Ministry of Information and Communications, Nuku'alofa, Kingdom of Tonga, March 12. Retrieved from

http://www.mic.gov.to/news-today/press-releases/4307-statementby-lord-vaea-57th-session-commission-on-status-of-women

Moala, K. (2012). Tonga struggles down long road to democracy. Pacific Institute of Public Policy, Port Vila, Vanuatu, May 16. Retrieved from

http://www.pacificpolicy.org/blog/2012/05/10/tonga-strugglesdown-long-road-to-democracy/

New Zealand Government. (2013). Pacific Energy Summit. Auckland, New Zealand, March 24-26. Retrieved from

http://www.pacificenergysummit2013.com/

Niumeitolu, V. (2010). Tongan (American) Creation Myth. Blackmail Press: Volume 31, Auckland, New Zealand. Retrieved from

http://www.blackmailpress.com/VM31.html

NZ Aid Programme. (2012). Ceremony marks opening of Tonga's first solar farm. New Zealand Aid Programme, New Zealand Ministry of Foreign Affairs and Trade, Wellington, New Zealand, July. Retrieved from

http://www.aid.govt.nz/media-and-publications/developmentstories/july-2012/ceremony-marks-opening-tongas-first-solarfarm

NZ Aid Programme. (2013a). Leading Lights in Renewable Energy. New Zealand Aid Programme, New Zealand Ministry of Foreign Affairs and Trade, Wellington, New Zealand, February. Retrieved from http://www.aid.govt.nz/webfm_send/345

NZ Aid Programme. (2013b). Tonga: Snapshot. New Zealand Aid Programme, New Zealand Ministry of Foreign Affairs and Trade, Wellington, New Zealand, April 11. Retrieved from http:/ / www.aid.govt.nz/where-we-work/pacific/tonga

NZ Ministry of Foreign Affairs and Trade. (2013). Kingdom of Tonga. New Zealand Ministry of Foreign Affairs and Trade, New Zealand Government, Wellington, New Zealand, April 10. Retrieved from http://www.mfat.govt.nz/Countries/Pacific/Tonga.php\#bilateral 
Pacific Islands Forum Secretariat. (2013a). Pacific Forum to Conduct Case Study of Tonga Energy Plan. Pacific Islands Forum Secretariat, Suva, Fiji, March 28. Posted by Pacific Islands Report, East-West Center, Honolulu, Hawai'i, USA. Retrieved from http://pidp.eastwestcenter.org/pireport/2013/March/03-29-rl.htm

Pacific Islands Forum Secretariat. (2013b). Pacific Islands Forum Secretariat: Excelling Together for the People of the Pacific. Pacific Islands Forum Secretariat, Suva, Fiji, April 8. Retrieved from http:/ / www.forumsec.org/

Pacific Network on Globalisation. (2012). Fool Me Once: The Tongan W.T.O. Experience. Pacific Network on Globalisation Organisation, Suva, Fiji, June 13. Retrieved from

http:/ / www.youtube.com/watch?v=-0pUC6fxQIs

Pelling, M. and Uitto, J. (2001). Small island developing states: Natural disaster vulnerability and global change. Global Environmental Change Part B: Environmental Hazards, 3 (2): 4962.

Radio New Zealand International. (2013a). Tonga MP says accountability depends on politicians laying policy platforms. Radio New Zealand International, Auckland, New Zealand, April 2. Retrieved from

http: / / www.rnzi.com/pages / news.php?op=read\&id=74991

Radio New Zealand International. (2013b). Tonga government distracted from pursuing greater accountability and transparency. Radio New Zealand International, Auckland, New Zealand, April 3. Retrieved from

http: / / www.rnzi.com/pages / news.php?op=read\&id $=75038$

Radio New Zealand International. (2013c). New Zealand aid policy mystifies Pacific civil society groups. Radio New Zealand International, Auckland, New Zealand, April 3. Retrieved from

http:/ / www.rnzi.com/pages / news.php?op=read\&id=75024

Said. E. W. (1978). Orientalism. London, United Kingdom: Routledge and Kegan Paul.

Schumpeter, J. A. (2008). Capitalism, Socialism, and Democracy: Third Edition. New York, USA: Harper Collins.

Slatter, C. (2006). Treading Water in Rapids? Non-Government Organisations and Resistance to Neo-Liberalism in Pacific Island States. In Globalisation and Governance in the Pacific Islands, edited by S. Firth. Canberra, Australia: ANU E Press, Pp. 23-42.

Sojo, C. (2005). Venezuela's Chavez Closes World Social Forum with Call to Transcend Capitalism. Venezuela Analysis, Caracas, Venezuela, January 31. Retrieved from

http://venezuelanalysis.com/news/907

Spivak, G. C. (1990). The Postcolonial Critic: Interviews, Strategies, Dialogues. London and New York: Routledge.

Strelitz, L. and Steenveld, L. (1998). The Fifth Estate: Media Theory, Watchdog of Journalism. Ecquid Novi: African Journalism Studies, 19 (1): 100-110. 
Stuff New Zealand. (2012). After Kyoto: NZ aims for bulk emissions. Stuff New Zealand, Auckland, New Zealand, December 10. Retrieved from

http://www.stuff.co.nz/national/politics/8056993/After-Kyoto-NZaims-for-bulk-emissions

Talakai, M. (2012). Climate Conversations: Small Island States Need Action on Climate Loss and Damage. Alert Net: Thomson Reuters Foundation Service, London, United Kingdom, August 30. Retrieved from

http://www.trust.org/alertnet/blogs/climate-conversations/smallisland-states-need-action-on-climate-loss-and-damage/

The Economist. (2012). Climate Conference: What Doha Did. The Economist, New York, USA, December 15. Retrieved from

http://www.economist.com/news/international/21568355-noprogress-today-slightly-better-chance-progress-tomorrow-whatdoha-did

Tonga - New Zealand Joint Commitment for Development. (2011). Tonga - New Zealand Joint Commitment for Development: Mutual Commitments. Government of Tonga and the New Zealand Government, Nuku'alofa, Kingdom of Tonga, July 13, Pp. 1-11.

TransNet NZ Ltd. (2013). TransNet Tonga. TransNet New Zealand Limited, Auckland, New Zealand, April 7. Retrieved from

http://www.transnet.co.nz/contacts/

United Nations. (1998). Kyoto Protocol to the United Nations Framework Convention on Climate Change. New York, USA, Originally Signed on December 11, 1997.

http://unfccc.int/resource/docs/convkp/kpeng.pdf

United Nations. (2011). United Nations General Sixty-Sixth General Assembly, Plenary 3rd 4th 5th Meetings: Non-Communicable Diseases Deemed Development Challenge of Epidemic Proportions in Political Declaration Adopted During Landmark General Assembly Summit. UN Department of Public Information, New York, USA, September 19. Retrieved from

http://www.un.org/News/Press/docs/2011/ga11138.doc.htm

Wallerstein, I. (1979). The Capitalist World-Economy: Essays by Immanuel Wallerstein. Cambridge, United Kingdom: Cambridge University Press.

Wolf, E. (1982). Europe and the People without History. Berkeley and Los Angeles, California, USA: University of California Press.

\section{Photographs}

Auckland, New Zealand, Teena Brown Pulu, 2013.

Hahake District, Kingdom of Tonga, Teena Brown Pulu, 2013.

Nuku'alofa Waterfront, Kingdom of Tonga, Teena Brown Pulu, 2013.

Sopu, Kingdom of Tonga, Teena Brown Pulu, 2013.

Kolonga, Kingdom of Tonga, Teena Brown Pulu, 2013.

Nuku'alofa, Kingdom of Tonga, Teena Brown Pulu, 2013. 


\section{Tongan glossary}

Ta'ovala

Hand-woven mat worn by Tongans

Vala Tupenu

Wrap-around garment worn under a hand-woven mat 